\title{
Philosophy of Education and Its Significance
}

\author{
Supriyanto \\ Pengembang Kerja Sama Pascasarjana \\ IAIN Surakarta \\ antosupriyanto1973@gmail.com
}

\begin{abstract}
Absract
Education is a very important capital of life in the lives of humanity. However, education sometimes cannot develop sustainably without being approached with a philosophical approach. Education requires philosophy to open its perspective in order to be able to respond to various actual problems that always arise in the world of education. The nature of education is a process of learning and searching, as well as the development of knowledge that has no finishing point. In this frame of meaning, true education is an intellectual, emotional, as well as spiritual ascent all towards new peaks. And one of the keys that is able to uncover that awareness is philosophy. Therefore, this paper will try to explore the understanding and meaning of educational philosophy, the significance of philosophy on education, educational goals, and concludes with a conclusion.
\end{abstract}

Keywords: Philosophy, Education, Significance

\section{A. Introduction}

To feel oneself en route, to feel onself in place where there are always possibilities of clearings, of new opening, this is what we must communicate to the young if we want to waken them to their situations and enable them to make sense of and to their worlds name. ${ }^{1}$ (Maxine Greene)

"Feeling on the way or in a place where there is always the possibility of new explanations and openness, this awareness must be communicated to young people if we are to make them aware of their condition and make them able to understand and identify their world".

\section{2.}

\footnotetext{
${ }^{1}$ Joy A. Palmer (ed), Fifty Modern Thinkers On Education, (London: Routledge, 2001), p.
} 
The sentence above is expressed by one of America's most famous philosophers of education, Maxine Greene in one of his works Releasing the Imagination. As revealed above, Greene wants how the nature of education is not a static place to be achieved; not a destination that you want to visit, and not a project that should be pursued by students.

The nature of education is a revelation that every student is always on his way, an awareness of the possibility of new explanations and new openings (there are always possibilities of clearings, of new opening). That is the journey of enlightenment in the world of education. That means education is a process of learning, searching, as well as the development of knowledge that has no finishing point.

In this frame of meaning, true education is an intellectual, emotional, as well as spiritual ascent all towards new peaks. And one of the keys that is able to uncover that awareness is philosophy. Therefore, this chapter will try to explore the understanding and meaning of educational philosophy, the significance of philosophy on education, the scope of educational philosophy, educational objectives, and concludes with a conclusion. Some of these issues will be explored in this chapter, so that they can become a kind of snapshot of educational philosophy.

\section{B. Definition of Educational Philosophy}

Discourse about educational philosophy is a combination of two words, philosophy and education. Therefore, to uncover the holistic understanding of the philosophy of education, it should unravel the understanding of the two words respectively. The term philosophy comes from the Greek: philosophia, which means "love of wisdom, knowledge, skills and practical experience". Philosophy in that sense shows that human beings have never perfectly had a comprehensive understanding of everything that is meant by wisdom, but must constantly pursue it. Regarding what it does, philosophy is knowledge possessed by human ratios which penetrate the last foundations of all things. Philosophy wraps over all reality, but especially human existence and purpose. $^{2}$

Whereas the term education, in English; education, rooted in Latin, educare, which can be interpreted as "continuous guidance (to lead forth)". If expanded, the etymological

\footnotetext{
${ }^{2}$ Lorens Bagus, Kamus Filsafat, (Jakarta: Gramedia Pustaka Utama, 2002), p. 242-243.
} 
meaning reflects the existence of education that lasts from generation to generation throughout the existence of human life. ${ }^{3}$

This meaning is in line with the notion of education expressed by Napoleon Hill in a different Latin namely educo. The term educo means to develop from within; to draw out, to go through the law of use. Which freely means to improve the quality of ourselves from within, then develop it, and be able to apply all the knowledge that has been achieved in a useful way. ${ }^{4}$

Meanwhile, the term education in the termonology of our religion is called tarbiyah, which contains the basic meaning as growth, improvement, or make something higher. Because the basic meaning of growth or increase, then this assumes that in every human being there are seeds of goodness. It is the duty of parents and educators to develop the positive seeds of their students as well as possible. Thus, education (tarbiyah) is a process of increasing the positive potentials that reside in the soul of every child to achieve the highest quality, and the educational process never ends as long as life is still contained in the body. ${ }^{5}$

According to Suparlan Suhartono, the meaning of education can be seen from two perspectives namely broad and narrow meanings of education. In a broad sense, education is all learning activities that take place throughout the ages in all situations of life activities. Education takes place in all types, forms, and levels of the environment, which then encourages the growth of all the potential that exists in individuals. In these learning activities, individuals are able to change and develop themselves into increasingly mature, intelligent, and mature. So in short, education is a system of processes of change towards maturity, intelligence, and self-maturation. Mature in terms of body development, intelligent in terms of mental development, and mature in terms of behavior. In the next step in educational activities, these three goals become the framework for civilizing human life. $^{6}$

\footnotetext{
${ }^{3}$ Suparlan Suhartono, Filsafat Pendidikan, (Yogyakarta: Ar-Ruzz Media, 2009), p. 77.

${ }^{4}$ Napoleon Hill, Membangun Otak Sukses, terj. Teguh Wahyu Utomo (Yogyakarta: Baca, 2007), p. 109.

${ }^{5}$ See in Nurcholish Madjid, Masyarakat Religius (Jakarta: Paramadina, 2000), p. 83-84; See also in his book, Dialog Keterbukaan (Jakarta: Paramadina, 1998), p. 250.

${ }^{6}$ Suparlan, Filsafat..., p. $79-80$.
} 
In a broad sense, basically education is compulsory for anyone, anytime, and anywhere, because being mature, smart, and mature is a human right in general. It means that education must indeed take place at every type, form and level of the environment, starting from the individual environment, social family, community environment at large, and lasts all the time. So, educational activities take place by filling every inch of life.

From this information, a lesson can be drawn that education is an effort to make humans good, in the sense of their lives becoming more developed. With education, humans try to improve their lives from an instinctive level of life to rational culture. Therefore, education can be interpreted as civilizing human life. ${ }^{7}$

In addition to educational activities oriented to material culture, it is also directed at 'spiritual culture'. In this case, educational activities are focused on how to change and develop thinking patterns, taste patterns, and behavior patterns. The impetus for the development of spiritual culture is to compensate for the speed of material culture. Assuming, if the development of material culture is not matched by spiritual culture, it may actually threaten the existence of this life. Because the material innate nature tends to be mere physical change, while the range of development of spiritual culture is carried out with the aim of establishing a philosophy of life, guidelines for life, attitude to life, and cultural behavior. All kinds of changes created by material culture are then framed by spiritual culture in order to become a development that is of human value for survival.

Thus, in all educational activities, the two types of culture are not dichotomous, but are arranged causally-dialectically. Spiritual culture is positioned and functioned as the basis and source for material culture. For example, to increase the effectiveness and efficiency of work, 'a car' can only be interpreted and functioned as a means of transportation; a 'house' is only interpreted and functioned as a place to build family and community life; etc.

From various separate philosophical and educational understandings, educational experts also formulated a number of notions of educational philosophy. According to alSyaibani, educational philosophy is an organized activity of the mind, which makes philosophy a way to regulate, harmonize and integrate the educational process. That is, the

\footnotetext{
${ }^{7}$ Ibid., p. 81-82.
} 
philosophy of education can be explained values and proclamations that are sought for human experience is an integral factor.

Educational philosophy can also be defined as philosophical rules in the field of education that describe aspects of the implementation of general philosophy and focus on the implementation of the principles and beliefs that form the basis of general philosophy in an effort to solve educational problems in a practical way. ${ }^{8}$

According to Hasan Langgulung in his discussion of the philosophy of education was given the following definition:

a) Philosophy of education is the application of philosophical methods and views in the field of human experience called education. Educational philosophy is to look for concepts that can harmonize the different symptoms in education and an overall plan, explain educational terms, propose basic principles or assumptions on which specific statements about education are established and disclose classifications. Which is related between education and the fields of human personality.

b) Philosophy of education is an organized thought activity that makes philosophy as a medium for organizing the educational process, harmonizing, harmonizing, and applying the values and goals that it wishes to achieve. So here philosophy, philosophy of education and human experience are the three elements for a unified whole.

c) Educational philosophy is the activity carried out by educators and philosophers to explain the educational process, harmonize, criticize and change it based on the problems of cultural contradictions.

d) Educational philosophy is the theory or ideology of education that arises from the philosophical attitude of an educator, from his experiences in education and life from his studies of various sciences related to education, and based on that educators can find out about developing schools.

8 Jalaluddin dan Abdullah Idi, Filsafat Pendidikan: Manusia, Filsafat, dan Pendidikan, (Jakarta: Rajawali Pers, 2011), p. 6. 
Why do you study? What is the relationship between schools and other social institutions? What is the nature of the education process? And what is the nature of educational goals? And so forth. ${ }^{9}$

Based on the description of experts on the philosophy of education in accordance with reality (enthusiasm and having an applied interest and guidance in the field of education), the philosophy of education is the applied philosophy of education to educational problems or philosophy applied in a business of thought (philosophical analysis) regarding educational problems.

At this point, almost all education experts agree to say that educational philosophy contains the meaning of critical, systematic, and radical thinking about various educational problems in search of concepts and ideas that can direct humans in integral designs so that education can truly answer the needs of the community in order to progress. ${ }^{10}$

\section{Significance of Philosophy of Education}

In Haryatmoko's perspective, philosophy provides the basis for a rational culture for a mature and responsible society. Philosophy helps ensure that the goal always determines the choice of means, sharpens in explaining art, developing skills. The purpose of education is to foster in learners freedom so as to form moral subjects that are responsible. Knowledge that makes it possible to explain, control, and predict remains based on moral ideals to educate subjects who are independent, dignified and able to live together in a plurality of nations.

Why does an effective pedagogy presuppose philosophical understanding? One of the complicated factors of the education problem is the overlapping layers of problems. There are three main layers of educational problems, namely the anthropological, epistemic, and political layers.

First, the anthropological layer starts from the presupposition that humans are creatures that must be educated. Education becomes the specialty of humans who live in language culture. Language becomes the specialty of humans compared to other creatures. Education helps humans to regulate themselves and manage their relationships with others. Education makes life easier in society. Communities have demands for reproduction, maintenance, and developing their habitat. In a democratic society, its members will not be

\footnotetext{
${ }^{9}$ Prasetya, Filsafat pendidikan, (Bandung: Pustaka Setia, 1997), p. 22-23.

${ }^{10}$ Muhmidayeli, Filsafat Pendidikan, (Bandung: Refika Aditama, 2011), p. 35.
} 
allowed to live in ignorance. They are required to be free, independent and integrate the means for their freedom. So they learn to be able to fight for their rights. So the problem of education always arises as a collective problem and is compulsory for all people. Meaning that is only measured from an economic perspective ignores education that empowers people to become more free and able to integrate the means for their independence.

Secondly, the epistemic layer becomes important because modern society carries a peculiarity by redefining the object-stakes in delivery (values or knowledge or skills) and institutional modalities. Epistemic layer takes into account the whole knowledge or meaning structure (conception of the world, humans, society, knowledge, philosophy) that is specific to a particular group of people and at a particular time. Most education takes place in schools. Schools cannot be separated from the use of methods, but rational subjects must still be taken into account as a major factor in the dissemination and application of knowledge.

At a deeper level of culture, namely the cognitive structure that is driven by culture, schools cannot be separated from the history of science. In school culture, reflexive mediation between the subject of knowledge and the knowledge or values or skills acquired determines the place and role of the instructor. With a note of pressure on the development of subjects that learning means at the same time building themselves as rational subjects, it means being able to learn. People cannot learn on their own, but need the help of a third party.

Knowledge that bridges between subject and knowledge is called pedagogy. At this epistemic layer too, the students' openness to change is emphasized. To change means to modify a part of the habit and framework of interpretation. In this perspective learning is not accumulating knowledge, but organizing knowledge, which will change the way the world reads. In the learning process that occurs is the fusion of the horizons, between the horizons of students, the facilitator and the world or the field that opens new horizons. Learning means changing. At this epistemic layer, we want to answer questions about the tendency of social segregation in Indonesia on the basis of religion, but also the problem of weak competency of tertiary graduates.

Third, it is called the political layer because education has become a concern of state life and a public problem. In this layer, the challenges of education enter in the face of a weak sense of nationality. This political layer becomes one of the main directions of 
political progress. In this political layer education is expected to enable the implementation of three elements of integration:

1) Integration of the nation's culture as a political entity;

2) Social integration because thanks to education someone can get a place in society (especially the profession);

3) Subjective integration that defines moral values that allows each individual to be independent as a political and social creature.

These three integrations show that people's happiness can be achieved through education. Education then becomes an imperative that is not negotiable for a nation. In this context, the formulation of the basic needs for learning as declared in The World Conference on Education for All becomes very meaningful. In a statement said:

"The basic learning needs include both basic learning tools (reading / writing, speaking ability, counting, and problem solving) as well as content (knowledge, skills, values, and attitudes) needed by humans to survive, to be able to develop abilities they fully, live and work according to their dignity, participate fully in development, improve their quality of life, obtain information for their decisions and always learn in a sustainable manner". ${ }^{11}$

Meanwhile, according to Suparlan Suhartono, philosophy is very significant for education because the reality of human life today is sharply divided into two sides, namely:

1) Between the ruler (subject) and the party controlled (object), politically-sociality tends to be characterized by 'cruelty'.

2) Between the oppressors and the oppressed, legally the social life is not just.

3) Between the bourgeoisie and the destitute, economically social life has not been evenly distributed.

4) Between highly respected and humiliated parties, culturally, social life has not been imbued with human values.

The steep ravines that divide sharply into two sides in each dimension of life is what causes social conflict to become a 'tradition' which at times threatens social stability. Such facts of life encourage the need to rebuild an educational philosophy in accordance with the nature of human life. With the new education philosophy, it is hoped that the $192-195$.

${ }^{11}$ Haryatmoko, Dominasi Penuh Muslihat, (Jakarta: Gramedia Pustaka Utama, 2010), p. 
implementation of education can harmonize the goals of education with the goals of human life, so that the gap can be bridged and the road to life development becomes more spacious.

Philosophy is the parent of all fields of study and scientific disciplines, with a comprehensive perspective of 'nature'. That is, philosophy views each object in terms of its nature. While education is a field of study as well as a scientific discipline whose specific problem is 'developing human potential to become more mature and maturity human potents. Thus, educational philosophy has a central problem in the form of the maturation of human potential. The philosophy also is always dialectical thinking from a metaphysical, theoretical, to a practical level. The metaphysical level is called the ontology aspect, the theoretical level is called epistemology, and the practical level is called the ethical aspect.

If applied to educational activities, the ontology aspect is an educational process with an emphasis on the establishment of 'philosophy of life', a view of life imbued with the value of honesty. From this philosophy of life, it is expected that there will be growth and development of spiritual maturity, in the form of a comprehensive insight into the origin, existence, and purpose of life. While aspects of educational epistemology emphasize the system of educational activities in 'scientific attitude formation' (scientific attitude), an attitude imbued with truth values.

From the scientific attitude, it is expected that there is growth and development of intellectual maturity, in the form of creativity and life skills (creativities and skills of life). While the ethical aspects of education emphasize the system of educational activities in 'developing responsible behavior', a behavior imbued with the value of justice. With this responsible behavior, it is hoped that emotional maturity can grow and develop, that is, the ability to control oneself not to do acts that exceed the limits.

The three levels of the system of educational activities are interconnected with each other causally. The ontology aspect underlies the epistemology aspect and the epistemology aspect provides a path or method to the ethical aspect, while the ethical aspect is the result. With emotional maturity, it means that moral wisdom will grow and develop. The moral form of wisdom is in the form of fair behavior towards oneself, each other, its nature, and towards its Prima Causa. 
Furthermore, it can be assumed that if the educational philosophy paradigm is used as a basis for the implementation of education both within families, schools, and in community life, it can be expected that people's lives can be encompassed in the values of honesty, truth, and justice. Thus, the development of community life is culturally humane is expected to be realized.

From the description of the contents and meaning of education above, it can be understood that the scope of education covers all aspects of human life and takes place continuously. Education starts from family life, then is processed effectively and efficiently as well as methodical and systemic in school institutions to then be continued in social life in the form of various activities in various types of work.

So, education is a process that is not only limited to learning to just know an object (to know something what), but continues to expertise and skills in creating and producing (to be able to create or produce something). Furthermore, all creativity is evaluated to be a new lesson, in order to realize new creativity that is more useful for the survival and development of life. So much so that the idea of education becomes a never-ending spiral circle.

The problem that then arises is how to facilitate connectivity (bridging) between the wide angle of education (in the family) with the narrow angle of education (in schools) and then in the angle of education (in society). In such a way that education really takes place in an ongoing process. The process can be formulated in the form of the following questions:

1) Is the (education) family able to provide ideal input on school education?

2) Is school education able to provide ideal input to the community?

3) Is community education able to provide ideal input to families?

However, from this problem emerged an attempt to find a way out, by trying to build a paradigm of educational philosophy. ${ }^{12}$

\section{Educational Objectives}

According to Haryatmoko, there are at least four goals that become educational idealism:

\footnotetext{
${ }^{12}$ Suparlan Suhartono, Filsafat Pendidikan......., p. 92-95.
} 
1) Acquisition of knowledge and skills (competencies) or the ability to respond to market demand,

2) Humanistic orientation,

3) Answering social, economic and justice challenges,

4) Progress of the sciences themselves..$^{13}$

First, the purpose of education is to emphasize the acquisition of knowledge and the ability to prepare students so that later they will get employment opportunities. Educational efforts are focused on acquiring specialized knowledge and skills to excel in their fields. Benchmarks of the success of this kind of educational model are students able to find employment with income levels that are appropriate to their level of education. So education is directed to make a contribution to the organization of public welfare by preparing people for employment. Acquiring these skills and knowledge is usually the most dominant goal why students choose certain schools or colleges. ${ }^{14}$

Competence is thus a resource for identifying and solving problems, preparing and making decisions. The above explanation further sharpens the meaning of competence as the ability to act effectively in complex situations using the knowledge or skills that have been acquired. Competence is the overall ability to coordinate knowledge, skills and 'existing ways' that is applied in a particular situation (can process incoming information, can overcome production problems). So the emphasis is not on knowledge, but the ability to use, empower certain knowledge or skills. Not only about the problem of technical mastery, but also directed at the production of meaning (can be applied and very relevant). ${ }^{15}$

The second educational objective emphasizes a humanistic orientation. Education is directed to help students develop reasoning abilities, the ability to take responsibility for their statements, beliefs and actions. The goal is to be able to understand the "what" and "why" of what is learned and increase the ability to organize experiences in systematic concepts. Thus education becomes the process of forming students' basic dispositions and

\footnotetext{
${ }^{13}$ Haryatmoko, Dominasi Penuh Muslihat. p. 196-197.

${ }^{14}$ Ibid., p. 197.

15 Ibid., p. 198.
} 
intellectual and emotional abilities in relationships with others, the environment and nature. ${ }^{16}$

Only people who get a strong education of humanistic orientation will be able to deal with rapid changes. They are people who are always ready to learn again and are open to new things and are critical of themselves and their environment. They realize that what is at stake is a dynamic process that varies according to one's ability to adapt to the possibilities offered by the environment. So someone's ability to adjust determines the business development or productivity of a group. ${ }^{17}$

The third educational goal is to answer social, economic and justice challenges. In this perspective, education is directed to prepare people to be able to recognize and explain the problems faced by society and then try to produce answers that are based on ethics. This goal cannot be separated from the intrinsic political dimension in education. As said by Paulo Freire (in the Pedagogy of the Oppressed) that education is essentially political engagement. Students are directed to develop into citizens who have skills in processing social processes, are committed to democratic values, which means they are able and participate in social, political and economic processes. Therefore the acquisition of knowledge and skills is not for its own sake and not for the sake of science itself, but for the service of human development, peace and welfare of society.

The yardstick for the success of this educational goal is the growth in learners' interest in critically understanding the ongoing changes in society. Education does not result in students being alienated from the way of life of lower-income countrymen. Learners become concerned about the problem of injustice, conflict, sensitive to suffering, needs and aspirations of the community. The growth of compassion in students encourages learning motivation for the purpose of liberation, welfare and peace. ${ }^{18}$

The fourth educational goal, namely the advancement of the sciences themselves. Usually this goal is more directly related to higher education and demands a special disposition. The fourth educational goal is to invite students to learn something for the progress of the discipline itself. Benchmarks of success are studies carried out to bring the

\footnotetext{
16 Ibid., p. 200 .

${ }^{17}$ Ibid., p. 202.

${ }^{18}$ Ibid., p. 2014.
} 
discovery of new theories. The challenge lies in addressing ethical issues and how to deal with or prevent the misuse of science and technology. ${ }^{19}$

If the purpose of education is directed to the development of science itself, the research requirements are demanded to the level of the discovery of a new paradigm (Thomas S. Kuhn, The Structure of Scientific Revolution):

1) The achievements of the theories found strikingly so that it attracted a group of scientists to carry out other scientific activities;

2) The theory opens a very broad perspective so that it gives the possibility to solve many problems;

3) Scientific work (law, theory, application and instruments) provides a model and gives birth to special and coherent traditions in scientific research;

4) Gives a newer and more stringent definition of the field of research.

One indicator to measure its success is if the results of research or writings published by lecturers or university researchers are widely used as a theoretical framework or as a reference for other researchers or writers. The results of the study were adopted for both government and private policy foundations. Even at the academic level, it becomes a guidebook for learning in tertiary institutions, and debate does not only stop at the academic sphere, but extends to public debate, which in turn will determine public policy and the direction of community development. Usually the focus on the development of science itself will be accompanied by an ethical concern.

The four educational objectives can actually provide a vision for political policy makers. It's just that the government should not only be directed by economic logic that emphasizes efficiency but ignores social logic that cares about justice and solidarity. Education should not only be enjoyed by the upper middle class, but must be an effective means of social mobility for a group of poor people. In addition to these pragmatic demands, education must help students to have skills in processing social processes, having a commitment to ethical values and democracy so that they are able to participate in the socio-political process. ${ }^{20}$

\footnotetext{
${ }^{19}$ Ibid., p. 2018.

${ }^{20}$ Ibid., p. 211-212.
} 


\section{E. Conclusions: Openness to the New Horizon of Science}

Reflecting on the exposition above, we find that educational philosophy is not only a way of looking at various ideas, but also about learning how to use these ideas in the best way. The philosophy of education becomes significant when educators recognize the need to think at the same time see what they are doing in the context of broader individual and social development. ${ }^{21}$

Moreover, when we look at the nature of educational goals. The intrinsic purpose of education is not just to gain knowledge and skills; form good characteristics and as a problem solver in society, but also necessitates the development of science itself. Here, we may agree with the statement of one of the philosophers of British education, Richard Stanley Peters: "Education, then, can have no ends beyond itself", ${ }^{22}$ That is, educational philosophy blows the spirit of the search for truth for the happiness of humanity, however, does not limit the search for that truth. Because when the truth search is stopped, because it has reached its peak, that's when the development of science stops too. That spirit of stagnation is not desired by the philosophy of education. 1992), xvi.

${ }^{21}$ Howard A. Ozmon, Philosophical Foundation of Education, (New Jersey: Prentice-Hall:

22 Joy A. Palmer (ed), Fifty Modern Thinkers on Education......., p. 118. 


\section{BIBLIOGRAFI}

Palmer, Joy A. (ed). Fifty Modern Thinkers On Education,. London: Routledge, 2001.

Bagus, Lorens. Kamus Filsafat. Jakarta: Gramedia Pustaka Utama, 2002.

Suhartono, Suparlan . Filsafat Pendidikan. Yogyakarta: Ar-Ruzz Media, 2009.

Hill, Napoleon. Membangun Otak Sukses. Terj. Teguh Wahyu Utomo. Yogyakarta: Baca, 2007.

Madjid, Nurcholish Masyarakat Religius. Jakarta: Paramadina, 2000.

Madjid, Dialog Keterbukaan. Jakarta: Paramadina, 1998.

Jalaluddin dan Abdullah Idi. Filsafat Pendidikan: Manusia, Filsafat, dan Pendidikan. Jakarta: Rajawali Pers, 2011.

Prasetya. Filsafat pendidikan. Bandung: Pustaka Setia, 1997.

Muhmidayeli. Filsafat Pendidikan. Bandung: Refika Aditama, 2011.

Haryatmoko. Dominasi Penuh Muslihat. Jakarta: Gramedia Pustaka Utama, 2010.

Ozmon, Howard A. Philosophical Foundation of Education. New Jersey: Prentice-Hall: 1992. 